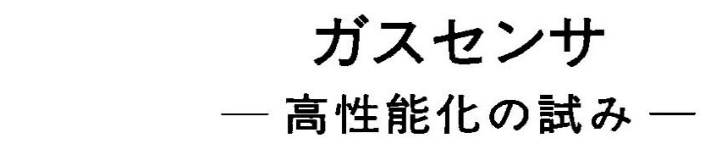

竹内 学*

*茨城大学 工学部（テ316-8511 茨城県日立市中成沢町 4-12-1）

\title{
Gas Sensors
}

\section{Manabu TAKEUCHI ${ }^{*}$}

*Faculty of Engineering, Ibaraki University (4-12-1, Nakanarusawa, Hitachi-shi, Ibaraki 316-8511)

Key Words: Gas Sensor, Ultrafine Particle, Thin Film, Copper Phthalopcyanine, Metal Oxide

\section{1. はじめに}

センサとは種々の物理量, 化学量などを電気量に変換して計測 するデバイスである。電気量に変換することにより，メータ表示， データ処理, 記録, 制御システムへの連動などが容易になる。ガ スセンサは気体(ガス)を測定対象とし，家庭の台所に設置され ているガス漏れ警報機がその典型である。ガス漏れ警報機はふん 曲気の可燃性ガス濃度がある值を超えると(可燃性ガスが漏れて いると)警報を発するが，一般には，ガスセンサにはガスの種類 を選択・識別し，その濃度を迅速に測定する機能が求められる。

ガスセンサに関してすでにいくつかの成書 ${ }^{1,21}$, 解説(1),4)があり 専門的知識はそれらを参照していただくとして，本稿では，筆者 の研究を紹介しながらガスセンサの高性能化における問題点を考 えてみたい。

\section{2. ガスセンサの動作原理}

はじめにガスセンサの動作原理をごく簡単に説明しよう。ガス センサは動作原理から，ガス成分が存在するときの，1）センサ 素子の電気伝導度の変化を測定する，2 )センサ素子の電位の変 化を測定する，3)その他，の3 タイプに大別できる5)。1)の夕 イプの例としては, $\mathrm{SnO}_{2}$ 系のガスセンサがあり, プロパンガス

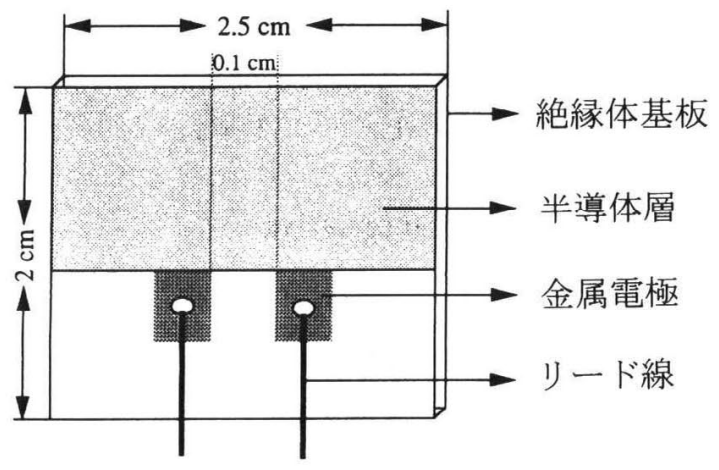

図 1 ガスセンサ素子の構造
の成分が吸着すると $\mathrm{SnO}_{2}$ の電気伝導度が増加することを利用す る。 $\mathrm{SnO}_{2}$ は $\mathrm{n}$ 型半導体であり, プロパンガス, 水素のような電 子供与性のガスが吸着すると電荷を運ぶキャリア数が増加して電 気伝導度が増加する。逆に酸素, $\mathrm{NO}_{2}$ のような電子受容性のガ スが吸着すると電気伝導度は減少する。 $\mathrm{p}$ 型半導体ではこの関係 はすべて逆になる。2)のタイプの例としては, 固体電解質型の 酸素センサがある。これは固体電解質である安定化ジルコニアの 両端に貴金属を取りつけた濃淡電池で，電極面の酸素濃度に応じ て発生する起電力を測定することにより，ふん囲気ガス中の酸素 濃度を知る。3)のタイプの例としては，接触燃焼式のガスセン サがあり，可燃性ガスが白金族系の触媒上で然焼するときの発熱 にともなう温度上昇を, 触媒の中に埋めた白金線の電気抵抗の変 化として測定する ${ }^{6}$ 。

一番簡単なガスセンサ素子の構造を図 1 に示す。一対の金属電 極を有する絶縁体(ガラス)基板上に半導体層が形成されている。 電極間に直流あるいは交流電圧を印加し，流れる電流のガス吸着 にともなう変化を観測する。これは，上述の1)のタイプのガス センサとして機能する。

\section{3. ガスセンサの高性能化の試み}

冒頭に述べたようにガスセンサはガスの種類を識別(選択)し， その濃度を迅速に測定することが必要である。もちろん実用的に は長時間安定に動作し，低価格であることも求められる。以下に， ガスセンサの高性能化のために筆者達が行っている試みをいくつ か紹介しよう。ただし，現時点ではいずれも実用化には至ってい ないことをお断りしておく。

\section{1 高感度化}

ガスセンサはできるだけ広い濃度範囲のガスを検出できること が望ましい。はじめに，ガスセンサの高感度化の試みを述べよう。 なお, ガスセンサの感度とはガス濃度の変化に対する電気量の変 化の割合であり, 高感度であるほど微量のガスも検出できる。

\section{1.1 超微粒子堆積膜}

ガスセンサの高感度化を図るには，単純には，それをある濃度 のガスふん囲気においたときできるだけ多くのガス分子がセンサ 


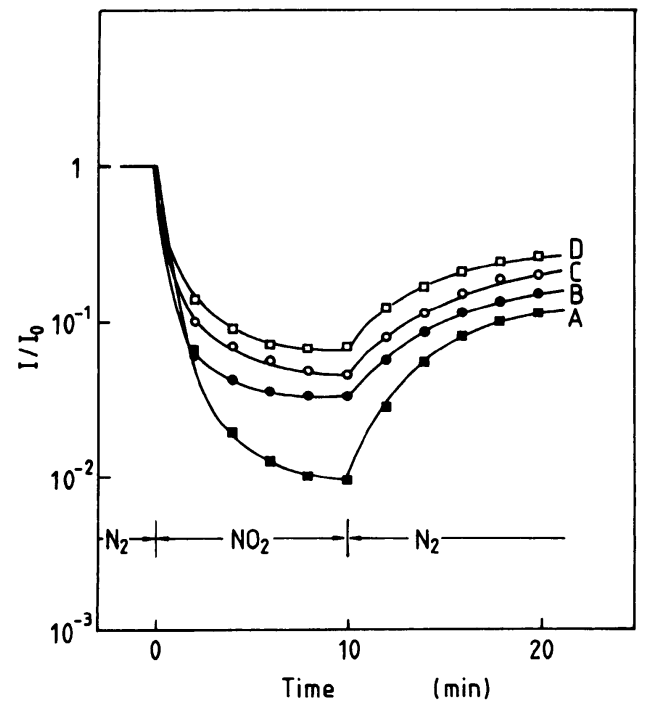

図 $2 \mathrm{ZnO}$ 超微粒子ガスセンサの電気伝導度の $\mathrm{NO}_{2}(0.1 \mathrm{ppm})$ 導入にともなう変化 超微粒子の平均粒径

A : $18 \mathrm{~nm}, B: 51 \mathrm{~nm}, C: 60 \mathrm{~nm}, D: 250 \mathrm{~nm}$

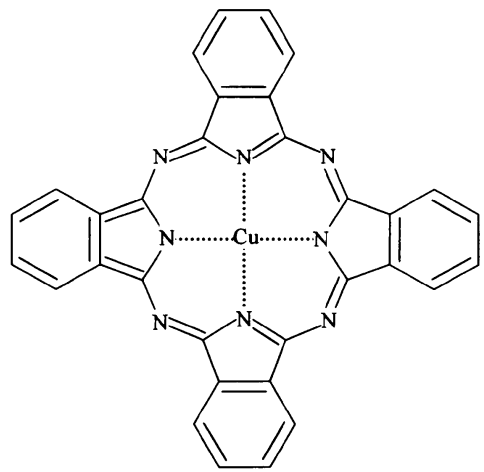

図 3 銅フタロシアニン分子

素子に吸着すればよい。そのためには，ガス分子の吸着できる面 積が大きければ大きいほどよい。すなわち, バルクの固体より薄 膜, 薄膜より微粒子の集合体(燒結体)のほうがよく, 実用に なっているガスセンサのほとんどは微粒子の焼結体を利用してい る。同じ焼結体でもそれを構成する粒子の粒径が小さいほど比表 面積が大きく, 感度が高い。そこで, 超微粒子の集合体を利用す ればさらに高感度になると期待される。

超微粒子の生成法の一つにガス中蒸発法がある。真空中で物質 を蒸発させ, 蒸気を基板上で固化させて薄膜を形成する技術が真 空蒸着である。真空蒸着と同じように物質の蒸発を少し気体が存 在するふん囲気で行うと, 薄膜の代わりに微粒子の堆積膜が得ら れる。通常この方法(ガス中蒸発法という)で得られる粒子は非 常に小さく，超微粒子と呼ばれる。

ガス中蒸発法により $\mathrm{ZnO}$ 超微粒子堆積膜を形成し, ガスセン サの高感度を試みた ${ }^{7)}$ 。ガス中蒸発法では, 物質を蒸発させるふ ん囲気の圧力を高くすると大きい粒子が，圧力を低くすると小さ い粒子が得られる。酸素とアルゴンの比を $1 ： 1$ とし，その全体 の圧力を 10-100 Torr の範囲で変化させて, 平均粒径が 18-250 $\mathrm{nm}$ の超微粒子堆積膜を一対の金電極 (ギャップ：1 mm)を形成 してあるガラス基板上に作製した。 $\mathrm{NO}_{2}(0.1 \mathrm{ppm})$ 導入にともな

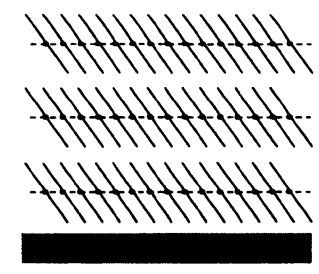

(a)

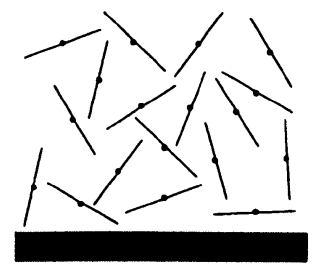

(b)
図 4 銅フタロシアニン薄膜

（a）多結晶膜，（b）アモルファス(非晶質)膜

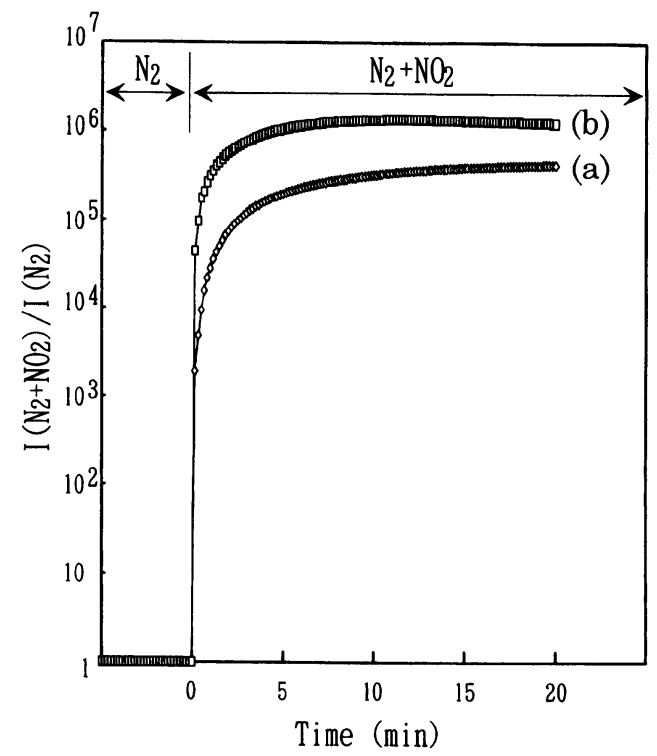

図 5 銅フタロシアニン薄膜の電気伝導度の $\mathrm{NO}_{2}(200 \mathrm{ppm})$ 吸着 にともなう変化

(a)多結晶膜，(b)アモルファス膜

う電気伝導度の変化を図 2 に示す。 $\mathrm{ZnO}$ 超微粒子の平均粒径が 小さくなるほどガス感度が高くなることが確認できる。なお, $\mathrm{ZnO}$ は $\mathrm{n}$ 型半導体であり, 電子受容性ガスである $\mathrm{NO}_{2}$ が吸着す ると電気伝導度は減少する。

\section{1. 2 アモルファス薄膜}

ガスセンサ構成粒子の微粒子化の極限は分子集合体である。銅 フタロシアニンは図3 のような平面状の分子で，中心に銅原子が 配位している。銅フタロシアニンは青色の顔料であるが, $\mathrm{p}$ 型の 有機半導体でもあり，ガスセンサへの利用が検討されている ${ }^{8), 99}$

銅フタロシアニン薄膜は通常の真空蒸着法により簡単に形成す ることができる。基板温度を室温(以上)に保つと図 4(a)のよう に銅フタロシアニン分子が積層した多結晶の薄膜が得られる。し かし，真空蒸着時に基板を冷却すると基板に入射して来た銅フ夕 ロシアニン分子はすぐにエネルギーを基板に奪われ整列(積層) する层がなく，固化する。その結果，図4(b)のように分子がラン ダムに積層した, すなわちアモルファス(非晶質)薄膜が形成さ れる。

アモルファス薄膜では分子間に空隙があるため気体分子の吸着 面積が大きく，ガスセンサとしては高感度になると期待される。 実際に, 銅フタロシアニンの多結晶薄膜とアモルファス薄膜を作 製して, $\mathrm{NO}_{2}(200 \mathrm{ppm})$ 吸着にともなう電気伝導度の変化を測定 すると, 図 5 のような結果が得られた ${ }^{10)}$ 。銅フタロシアニンは多 


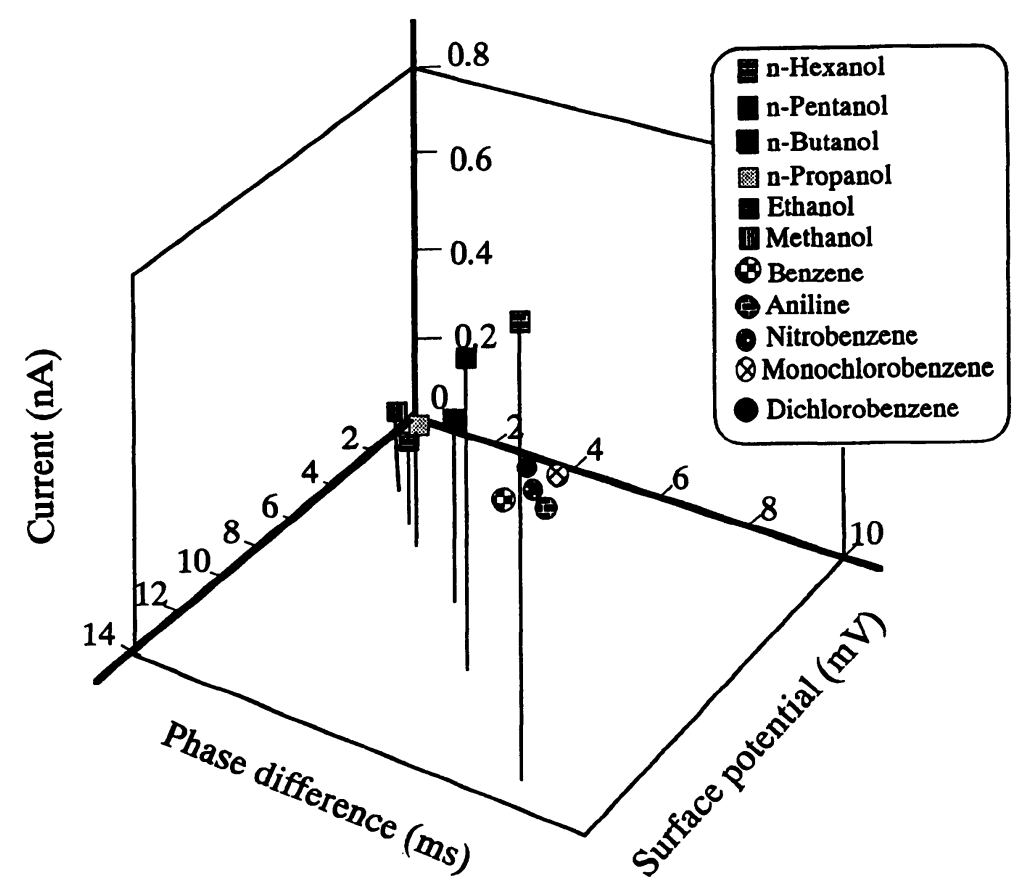

図 8 交流で動作するセンサによるアルコール類, ベンゼン類の識別

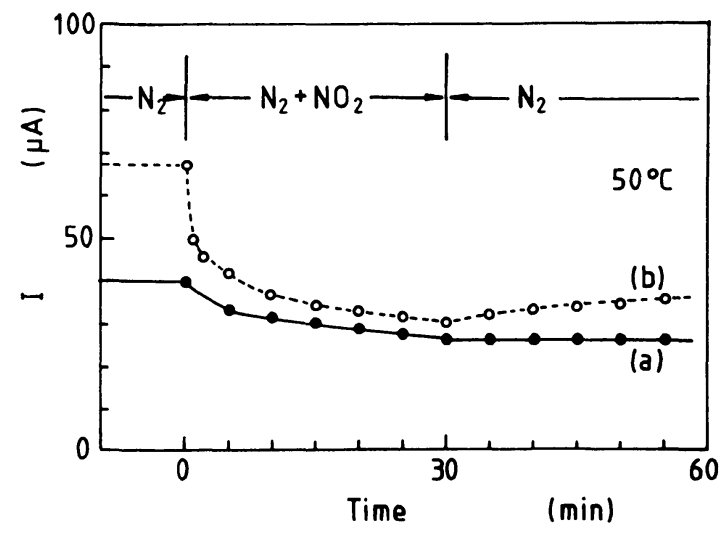

図 $6 \mathrm{TiO}_{2}$ センサ素子を流れる電流の $\mathrm{NO}_{2}(0.1 \%)$ の吸脱着に ともなう変化に対する光照射の影響 (a)暗所，(b)光照射下

結晶状態でも $\mathrm{NO}_{2}$ に対して高いガス感度を示すが, アモルファ ス状態にするとさらに高感度を示すことを確認できる。

\section{2 応答の高速化-光電導の利用}

前述のようにガスセンサの実用化には, 高いガス感度と並んで 高速応答性も必要である。すなわち, 対象とするガスがやって来 たときはすぐに応答し, そのガスがなくなれば迅速に元に戻るこ とが要求される。その目的のため, 通常ガスセンサは適度に加熱 した状態で使用される。すなわち, 高温にしてガス分子の脱着を 促進する。

多くの半導体は光電導性を有する。すなわち, 光が照射される とその電気伝導度が増加する。 $\mathrm{TiO}_{2}$ は $\mathrm{n}$ 型半導体であり, 紫外 光に対して光電導を示す。 $\mathrm{n}$ 型半導体であるから, $\mathrm{NO}_{2}$ が吸着 して電子が捕獲されると, 電気伝導度は減少する。ガス中蒸着法 により作製した $\mathrm{TiO}_{2}$ 微粒子堆積膜に直流電圧を印加して流れる 電流を観測した ${ }^{11)}$ 。ふん囲気を $\mathrm{N}_{2}$ から $\mathrm{N}_{2}+\mathrm{NO}_{2}(0.1 \%)$ に変 化させ，再びもとの $\mathrm{N}_{2}$ に戻すと図 6 に示すように電流が変化す

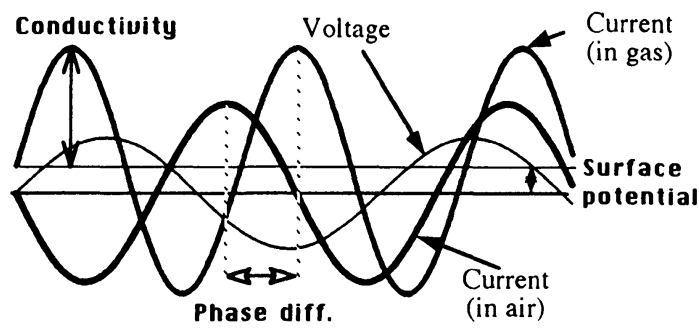

図 7 センサ素子に交流電圧を印加したときの電圧波形, 電流波 形，表面電位(ベースライン)

る。 $\mathrm{NO}_{2}$ 導入にともなう電流の減少と $\mathrm{NO}_{2}$ の脱着にともなう電 流の回復は暗所 (dark)より光照射下でのほうが速いことが確認 できる。 $\mathrm{TiO}_{2}$ における吸着分子の光脱着が原因と考えられるが, 詳細は現在のところ明確ではない。

\section{4. ガス選択性}

感度, 応答速度と並んでガスの選択性 (識別能力)がガスセン サでは重要である。家庭用ガス漏れ警報機の殺虫剤スプレーによ る誤作動がよく知られている。ガスセンサにガス選択性を保証す るため, いくつかの試みが行われている。たとえば, 数種類の夕 イプの異なるガスセンサを並列に準備しておき，それぞれのセン サの応答をパターン化して, やって来たガスの種類を識別しよう という試みがその一つである。あるいは，センサ素子に他の元素 を微量添加して触媒能に類似の機能を持たせるようにする試み, センサ素子の表面をある物質でコーティングする試みなどもある。

筆者らは, 単一のガスセンサでガスの識別を試みている。その ために, 通常のように電気伝導度, あるいは電位といった単一の 電気量を測定するのではなくて，単一のセンサに交流電圧を印加 し, 電気伝導度, 表面電位, 電流の位相遅れを同時に測定する。 センサ素子は図 1 に示したように単純で, $\mathrm{TiO}_{2}$ 粉末とバインダ 樹脂からなる厚膜を一対の金属電極を有するガラス基板上に形成 
したものである。

電極間に交流電圧 $(2 \mathrm{~V}, 30 \mathrm{~Hz})$ を印加して, オシロスコープ で印加電圧波形, 電流波形, 表面電位(ベースライン)を観測す ると図7のような結果が得られる ${ }^{12)}$ 。そして, 被検出ガスを導入 したときのこれらの量の変化を測定し, 表面電位, 電圧と電流の 位相差, 電流の絶対値を 3 次元プロットする。空気ふん囲気にこ のセンサを置き, 数種類のアルコール類, ベンゼン類を導入した ときの結果を図 8 に示す ${ }^{13)}$ 。濃度はすべて $500 \mathrm{ppm}$ である。ア ルコール類とベンゼン類では 3 次元座標上でのプロット点の位置 が異なることより，両者を大別できるだけでなく，アルコールの 種類, ベンゼンの種類をある程度識別することが可能である。こ のセンサに光照射を施すことによるガス検出感度の向上 ${ }^{14)}$, 表面 コーティングによるガス識別能力のさらなる向上 ${ }^{15)} も$ 試みてい る。

\section{5.むすび}

筆者の研究を中心に，ガスセンサの性能向上の試みをいくつか 紹介した。地球環境の破壊が進行する今日，ガスセンサの重要性 はますます増加している。すべての点で優れているガスセンサは， 犬の鼻に代表される動物の嗅覚器官である。我久人間も動物達に 教わりながらガスセンサのスマート化を図りたいものである。

(2001-3-14 受理)

\section{文献}

1）都甲 潔, 宮城幸一郎；センサ工学, p. 105, (培風館, 1995)

2 ) R. F. Taylor, J. S. Schultz ; Handbook of Chemical and Biological Sensors, p. 371, (Institute of Physics Publishing, 1996)

3 ) 山添 昇; 電気化学, 50, 29 (1982)

4 ) 白鳥昌之：表面科学, 10, 925 (1989)

5 ) 清山哲郎；電気化学, 50, 2 (1982)

6 ) 荒川 剛, 足立吟也, 塩川二朗; 電気化学, 50, 24 (1982)

7 ) M. Takeuchi, S. Kashimura, S. Ozawa ; Vacuum, 41, 7 (1990)

8 ）定岡芳彦, 山添 昇, 清山哲郎；電気化学, 46, 597 (1978)

9 ）定岡芳彦, 酒井義郎, 麻生 功, 山添 昇, 清山哲郎; 電気化学, 48, 486 (1980)

10) M. Masui, M. Sasahara, T. Wada, M. Takeuchi ; Appl. Surface Sci., 92, 643 (1996)

11) M. Takeuchi, Y. Watanabe, S. Ozawa ; Appl. Surface Sci., 48/49, 526 (1991)

12） M. R. Islam, 熊沢紀之, 竹内 学 ; 表面技術, 49, 1111 (1998)

13) M. R. Islam, N. Kumazawa, M. Takeuchi ; Sensors Actuators, B 46, 114 (1998)

14) M. R. Islam, N. Kumazawa, M. Takeuchi ; J. Electroanalytical Chem., 472, 137 (1999)

15) M. R. Islam, N. Kumazawa, M. Takeuchi ; Appl. Surface Sci., 142, 262 (1999) 